\title{
Erratum to: Prostaglandin actions in established insect cell lines
}

\author{
Yao-Fa Li ${ }^{1,2}$ • Hongwei Zhang ${ }^{1,3}$ • Joseph A. Ringbauer Jr ${ }^{1}$ Cynthia L. Goodman ${ }^{1}$ • \\ Tamra Reall Lincoln ${ }^{1} \cdot$ Kaile Zhou $^{1,3} \cdot$ David Stanley $^{1}$
}

Published online: 19 July 2017

(C) The Society for In Vitro Biology 2017

Erratum to: In Vitro Cell Dev Biol - Animal 53(5):421-429

DOI: 10.1007/s11626-017-0147-0

The X-axis of Fig. 2B should read PGA 2 (not $\mathbf{D}_{2}$ ).

The online version of the original article can be found at http://dx.doi.org/ 10.1007/s11626-017-0147-0

\footnotetext{
Cynthia L. Goodman

CINDY.GOODMAN@ARS.USDA.GOV
}

1 Biological Control of Insects Research Laboratory, USDA,

Agricultural Research Service, 1503 S. Providence Road,

Columbia, MO 65203, USA

2 Plant Protection Institute, Hebei Academy of Agricultural and Forestry Sciences/IPM Center of Hebei Province/Key Laboratory of Integrated Pest Management on Crops in Northern Region of North China, Ministry of Agriculture, Baoding 07100, China

3 Division of Plant Sciences, University of Missouri,

Columbia, MO 65211, USA 